\title{
12. MARIANA ARC AND FORE-ARC BACKGROUND AND OBJECTIVES ${ }^{1}$
}

\author{
D. M. Hussong, Hawaii Institute of Geophysics, Honolulu, Hawaii \\ and \\ S. Uyeda, Earthquake Research Institute, University of Tokyo, Tokyo, Japan
}

\begin{abstract}
When the IPOD South Philippine Sea drilling transect was first planned in 1974 , a relatively simple model for the geologic structure of active margin fore-arcsfrom the trench axis to the volcanic arc-was in use. Previous DSDP drilling in this environment had encountered only thick and young sediment on the Astoria fan and near the Aleutian Trench on Leg 18 (Kulm, von Huene, et al., 1973), although lower trench-slope sediments as old as late Miocene were subsequently recovered from the Aleutian fore-arc on Leg 19 (Creager, Scholl, et al., 1973). Site 298 on Leg 31, near the toe of the continental wall of the Nankai Trough, revealed sediment structures that were interpreted as a recumbent fold in the leading edge of the accretionary prism, where turbidites are initially deformed and uplifted from the trench axis (Karig, Ingle, et al., 1975).

The only other tool then available for studying deep sub-bottom structure in trench walls was multi-channel reflection seismology (MCS). Seely et al. (1974) had used such data to interpret the inner wall of the Middle America Trench off Guatemala as a large prism of accreted oceanic and trench-fill sediments that had been scraped off the subducting slab and uplifted by imbricate thrusting into the inner trench wall. A similar interpretation was made by Kulm et al. (1975) from MCS data across the Peru-Chile Trench fore-arc at $9^{\circ} \mathrm{S}$ latitude. Thus, most work on the deep structure of fore-arc areas had produced, by the mid-1970's, evidence for a simple model of ocean and trench-fill sediments being scraped off the subducting plate and accreting into the growing and uplifted overrriding continental, or island arc, plate.
\end{abstract}

There were some complications, however. The late Miocene sediments sampled on Leg 19 (Creager, Scholl, et al., 1973) contained an allochthonous block of middle Miocene nannofossil-bearing diatomaceous silty clay that had apparently subsided from its depositional depth to below the calcite compensation depth. An MCS profile across the Peru-Chile trench at $11^{\circ} 30^{\prime} \mathrm{S}$ was interpreted by Hussong et al. (1976) to show only a small accretionary prism at the toe of the continental trench wall, indicating that most oceanic sediments were being subducted and that the continental margin was actually subsiding and undergoing tectonic erosion. However, planning for IPOD active margin drilling was based on a simple model of an accreting margin. In the Marianas,

\footnotetext{
${ }^{1}$ Initial Reports of the Deep Sea Drilling Project, Volume 60.
}

this meant that two holes, one in the fore-arc sediment prism (Site Survey Target SP-2), and one in the arc volcanic chain (SP-3) would suffice to sample the major structural elements of this part of the island arc/subduction system.

Drill site selection surveys conducted by the Hawaii Institute of Geophysics in 1975 and 1976 (Hussong and Fryer, this volume) and Lamont-Doherty Geological Observatory (Mrozowski et al., this volume), verified previous suggestions that the Mariana fore-arc was somewhat more complex than suggested by the accretionary model. No sediments were found ponded in the trench axis, little sediment was found on the inner trench wall, and features with the bathymetric and geophysical character of igneous seamounts (Hussong and Fryer, this volume) were found in the middle of the fore-arc. Based on these results, the drilling plans were augmented to include a lower trench-slope target (SP2c), an upper trench-slope target (SP-3c), and a target (no site survey designation) on the active Mariana volcanic arc. An alternative site, designated SP-3b, was also proposed, located higher on the fore-arc between SP-3c and the volcanic axis site.

Thus by the beginning of Leg 60 , the time allocated to the fore-arc series of holes was small compared with what would be needed to solve the complex questions which were just beginning to be asked, including:

1) What is the nature of the basement material in the fore-arc region? Is it an accretionary wedge of slabs of Pacific plate oceanic crust that have been scraped off, emplaced and elevated by an imbricate thrusting process in front of the volcanic arc? Is any, or all, of the forearc the eastern remnant of the first island arc (perhaps the Palau-Kyushu Ridge?) that has been repeatedly displaced eastward with the opening of the western Pacific back-arc basins? Can the fore-arc contain other blocks of old ocean basin crust such as segments of the South Philippine Sea that have been trapped between the trench axis and the volcanoes? Does the frontal arc contain volcanics or other products of igneous activity that are related to presently undescribed tectonic events, such as the initiation of subduction? Is the fore-arc region a subsided remnant of a larger, perhaps even subaerial, segment of an old island arc or other large crustal mass which has been largely consumed by subduction?

2) Are there any recognizable trends in the age, petrology, or degree of chemical and physical alteration that can help us resolve the tectonic history of the island arc system? Is there any evidence of vertical motion, either subsidence or uplift, of the fore-arc? 
3) What is the physical state of the fore-arc region? Is it generally subject to compressional or tensional forces? What is the present degree of vertical tectonic activity? Why are there so few shallow earthquakes in the Mariana Trench area? Is there evidence of excessive water in the rocks above the subducting slab, which might be an effect of the subduction of oceanic crustal rocks that are apparently saturated with circulating bottom water? Are there tectonically over-pressured sediments in the fore-arc?

The segment of the reflection seismic profile obtained by the Challenger during transit from Hole 452A early in Leg 60 (Fig. 1) demonstrates the general character of the area between the trench axis $(0215 \mathrm{Z})$ and the ridge axis (1415Z). For this discussion, the profile can be divided into three segments: (1) the inner trench wall and trench slope break (0215 to 0600Z); (2) the outer fore-arc (0600 to 1030Z); and (3) the frontal arc (1030 to 1330Z).

The inner trench wall is probably the least known portion of the arc-trench region. Where adequate bathymetric control is available (Fig. 2), the general physiography suggests that the trench wall is composed of blocks that both incise the slope and cause topographic steps. Unfortunately, the relatively steep dip (averaging 9 degrees) of the inner wall, as well as stratigraphy that is probably very irregular and tectonically deformed, has prevented any useful sub-bottom penetration with seismic reflection techniques. Geologic sampling of the inner wall of the trench by dredging and piston cores has provided a suite of samples that includes sediments in all stages of lithification as well as limestones, basalts, alkali basalts, alkali gabbros, gabbros, and serpentinized ultramafic rocks. The variety of exposed rocks and the general physiography of the trench wall suggest that it is dominated by slump and normal-fault features, although the data are inconclusive. The top of the inner wall of the

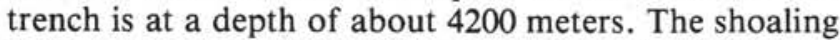
toward the axis of the island arc from that depth is gradual, although seamounts occur sporadically in the arc-trench region. Large portions of the trench-slope break are much shallower than $\mathbf{4 2 0 0}$ meters and form a pronounced bathymetric high on the trench-slope break (Fig. 2 near $18^{\circ} \mathrm{N}, 147^{\circ} \mathrm{E}$ ). These local highs have little gravimetric or magnetic expression, and thus seem to be composed of non-magnetic, low-density material. Geophysically, the material of this bathymetric high in the transect area has the appearance of a 1000-meter-high pile of sediment. This mound is situated on the opposite side of the trench from a seamount that is being subducted with the Pacific plate, but it is difficult to see how the proximity of these seamounts to the mound is anything more than coincidental. However, if the trench-slope break represents an upper limit of uplift of trench wall material by some subduction-related process, such as imbricate thrusting, the different elevations may be a reflection of irregular ocean-plate topography that has previously been subducted.

Regardless of the mechanism, it would seem that something must make room for the subduction of large seamounts, and the trench wall and fore-arc region is probably more easily deformed than the thicker subducting oceanic lithosphere.

Slightly west of $147^{\circ} 10^{\prime} \mathrm{E}$ (0630Z on Fig. 1), the geophysical character of the arc-trench gap region changes. Although the bathymetry is still subdued, large gravity and magnetic anomalies suggest that extensive igneous bodies compose the acoustic basement. Normal faulting is still persistent, but the sediments are relatively flatlying and reflectors can be readily traced through the deep sediment basins that occur between areas where the acoustic basement comes near the sea floor (2000Z on Fig. 1).

Further west, near $1200 \mathrm{Z}$ on Figure 1, a second band of sea floor relief marks the generally shallowest portion of the ridge. This region is offset about $30 \mathrm{~km}$ east of the axis of the active arc volcanoes, and is therefore in the same relative position as the frontal arc islands of Guam, Saipan, Tinian, etc. further south. At $18^{\circ} \mathrm{N}$, the uplifted sea floor is dominated by normal faulting (Mrozowski et al., this volume) and has magnetic and gravity anomalies similar to those of the outer fore-arc region (Hussong and Fryer, this volume). The basement irregularities on the frontal arc are covered by more sediment than the outer fore-arc area, but this may be a recent effect of being close to the presently active volcanoes and not indicative of the geologic history of the deeper material.

\section{REFERENCES}

Creager, J. S., Scholl, D. W., et al., 1973. Init. Repts. DSDP, 19: Washington (U.S. Govt. Printing Office).

Hussong, D. M., Edwards, P. B., Johnson, S. H., et al., 1976. Crustal structure of the Peru-Chile Trench, $8-12^{\circ} \mathrm{S}$. latitude. In Sutton, G. H., Manghnani, M. H., Moberly, R., and McAfee, E. D. (Eds.), The Geophysics of the Pacific Ocean Basin and Its Margin: Geophysical Monograph 19: Washington (American Geophysical Union), pp. 71-85.

Karig, D. E., Ingle, J. C., Jr., et al., 1975. Init. Repts. DSDP, 31: Washington (U.S. Govt. Printing Office).

Kulm, L. D., Prince, R. A., French, W., et al., 1975. Evidence of imbricate thrusting in the Peru Trench and continental slope from multi-fold seismic reflection data. EOS, Trans. Amer. Geophys. Union, 56:442-443.

Kulm, L. D., von Huene, R., et al., 1973. Init. Repts. DSDP, 18: Washington (U.S. Govt. Printing Office).

Seely, D. R., Vail, P. R., and Walton, G. G., 1974. Trench slope model. In Burk, C. A., and Drake, C. L. (Eds.), Geology of Continental Margins: New York (Springer), pp. 249-260. 

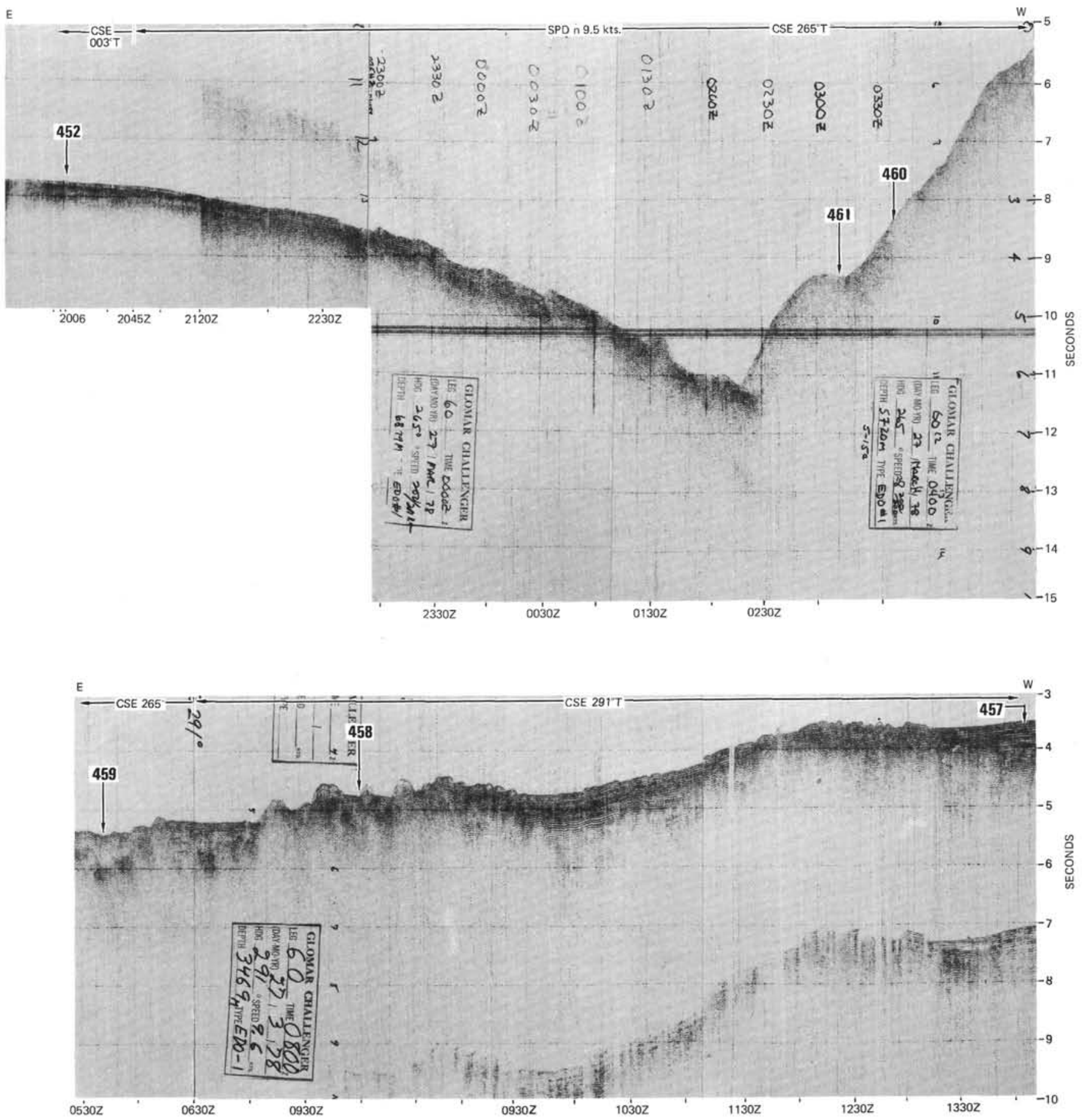

Figure 1. East-to-west reflection profile of the Mariana Trench fore-arc region from Site 452 to the vicinity of Site 457 , obtained by the Glomar Challenger during Leg 60 . Locations of Sites 457-461 are projections from actual locations which are not shown precisely on this profile. 


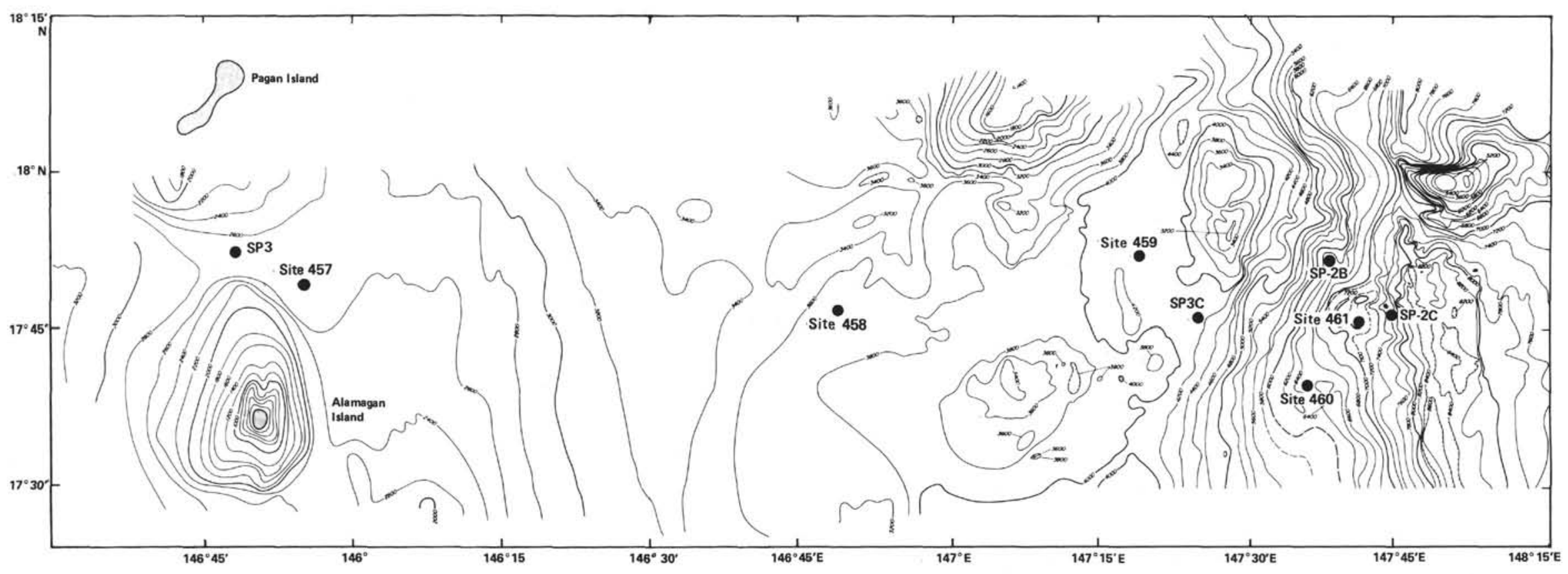

Figure 2. Bathymetry of the Mariana fore-arc region, 200-meter contour interval, with site survey (SP) targets and DSDP sites (Sites 457-460) shown. From Hussong, this volume. 